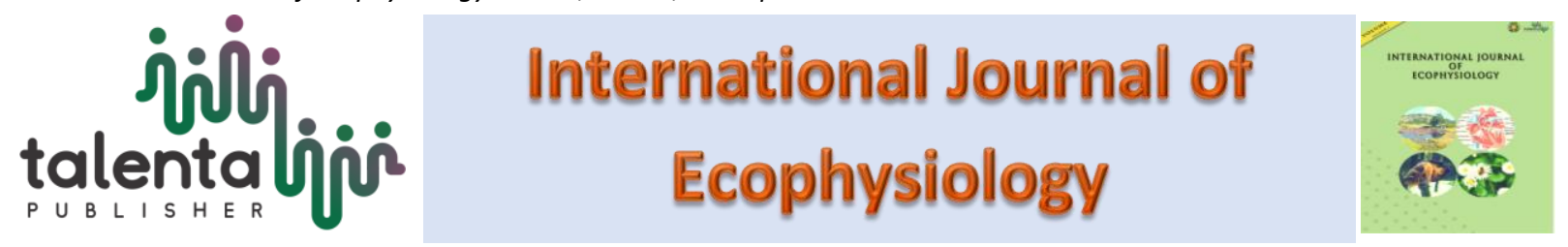

\title{
Monitoring of The Palm Oil Plantation Ecosystem Based on Land Macrofauna Diversity
}

\author{
Arlen Hanel John \\ Department of Biology, Faculty Mathematics and Natural Sciece, Universitas Sumatera Utara, Jalan \\ Bioteknologi No. 1 KampusPadang Bulan, Medan 20155, Sumatera Utara, Indonesia.
}

\begin{abstract}
Oil palm plantations of PT. Supra Matra Abadi has used palm oil mill effluent to the plantation area as fertilizer (Land Application) to part of its plantation area. The difference in land use and management in the plantation area also determines the presence, both species, density, diversity index value, and soil macrofauna uniformity index. Soil macrofauna plays a role in maintaining the balance of the soil ecosystem. This research has been conducted at PT. Supra Matra Abadi, located in Kebun Panji Bay, Kampung Rakyat District, Labuhanbatu Selatan Regency, North Sumatra Province in May-July 2018. This research was conducted to determine the presence of species, population density, diversity index values, and uniformity of soil macrofauna on oil palm plantations. Determination of the sampling point is done by the Purposive Random Sampling method, soil macrofauna sampling using the Quadratic and Hand Sorting methods. There are 15 species of soil macrofauna which are grouped into 2 phyla, 5 classes, 9 orders, 12 families, and 15 genera. The highest density value was found in the area of plantations that were not given liquid palm oil mill effluent as fertilizer (Non Land Application) of 282.15 ind / $\mathrm{m} 2$ and the highest diversity index value was found in the area of oil palm plantations which were fertilized with palm oil mill liquid waste to land area (Land Application) which shows that the condition of the oil palm plantation ecosystem which is fertilized with palm oil mill effluent (Land Application) can support the life, diversity, and uniformity of soil macrofauna.
\end{abstract}

Keyword: Soil Macrofauna, Density, Diversity, Uniformity, Soil Application.

Received 5 November 2019 | Revised 25 December2019 | Accepted 28 January2020

\section{Introduction}

Oil palm plantations from year to year always experience an increase and development, so that the land for the current plantation area is increasingly limited, even in some areas since 1987 there has been a conversion from rubber plantation land to oil palm plantations, and often the land is used continuously without regard to its maintenance, does not even provide an

*Corresponding author at: Jl. Bioteknologi No. 1 Kampus Univ. Sumatera Utara, Padang Bulan, Medan, Indonesia 
opportunity for the soil to renew its physical-chemical-biological condition naturally, or be restored to its fertility [1].

As a result of the increase and development of plantation activities from year to year causes the current land for the plantation area is increasingly limited, so that often the land is used continuously without regard to maintenance, not even giving the opportunity to the land to renew the physical-chemical-biological conditions naturally, or restored fertility. As a result of continuous land use the impact is seen in the decreasing level of soil fertility

The stated that the fertilizing treatment and application of herbicides is sustainable, as well as the scraping of harvesters or footrests, even the application of fertilizers that are very difficult to dissolve, such as Rock Phosphate and Doloinite will cause the soil in the disks to become more dense and compact. This condition causes the porosity of the soil to become narrow, so that drainage and respiration of roots, and soil biota will be disrupted, resulting in the difficulty of the root system and soil biota developing and activating on the soil.

Excessive use of chemical fertilizers can damage the physical, chemical and biological characteristics of the soil, as well as reduce the population and biodiversity of the soil, this condition causes the group of biota that perform certain functions to be destroyed thereby eliminating the role of the biota community from the soil ecosystem, Furthermore, Dewi [2] explained that the decrease in diversity of soil fauna was due to intensive land management, fertilization and monoculture planting in conventional farming / plantation systems.

Anwar et al. [3] and Hanafiah et al. [4] explained that biodiversity, including the presence of soil fauna, is a component in soil ecosystems that plays a role in improving soil structure, increasing pore space, aeration, drainage, water storage capacity, decomposition of organic residues, mixing of soil particles and microbial distribution.

Physical, chemical, and biological degradation of soils in most conventional agricultural / plantation systems in the long run is one of the serious problems for the sustainability of agricultural / plantation businesses. This situation will be detrimental, both for natural ecosystems and the welfare of farmers, but today there have also been found several palm oil plantation activities that have used variations of chemical fertilizers with organic fertilizers, namely by using organic fertilizers from crop residues, and coconut factory liquid waste. oil palm to the plantation area (land application system), including PT. Supra Matra Abadi.

The role of soil biology in increasing land productivity is becoming increasingly important, because of the increasingly widespread mismanaged agricultural / plantation land and the increasingly limited inorganic fertilizer resources. In terms of various types of soil microbes and fauna, they are known to have potential as biological fertilizers, and various soil biological attributes have been widely used as indicators of soil quality and health. 
Foth [5] explains that the application of plant organic material to the soil can improve the physical, chemical, and biological properties of the soil. The existence of plant organic matter is possible to increase the activity of soil fauna, because organic material is used as an energy source and food source for its survival. Furthermore Kartini [6] states that in an effort to overcome soil damage, the physical, chemical and biological soil factors need to be addressed so that crop production can be maintained properly. Thus it is necessary to conduct a fertilizer assessment, especially the application of organic fertilizer to the soil given that the C-organic soil content managed by farmers is generally low.

\section{Materials and Methods}

\subsection{Time and Place}

This research was conducted in May 2018 until July 2018 in the palm oil plantation area of PT. Supra Matra Abadi which is located in Kebun Panji Bay, Kampung Rakyat District, Labuhanbatu Selatan Regency, North Sumatra Province. Furthermore, identification and analysis of data from soil macrofauna samples were obtained at the Ecology Laboratory of the Department of Biology, USU FMIPA Medan

\subsection{Research Methods}

This research was conducted using the Survey Method, and the determination of the location of the sampling plot was carried out using the Purposive Random Sampling method, namely by selecting a random location on an oil palm plantation. Furthermore, soil macrofauna sampling was carried out using the Quadratic and Hand Sorting Method.

\subsection{Research Implementation}

a) Soil Macrofauna Sampling

Soil Macrofauna samples were taken using the Quadratic and Hand Sorting method, at a predetermined location of an oil palm plantation, a $30 \times 30 \mathrm{~cm}$ plot was made with a Stainless Steel Monolite, the sampling was carried out with the distance between each square closest to $10 \mathrm{~m}$. The soil from each square is taken $20 \mathrm{~cm}$ deep and the soil is put into burlap (plastic sacks). Sampling was conducted at 06.00-09.00 WIB. Furthermore, the soil is sorted directly to get soil Makrofauna. Soil macrofauna obtained were collected and cleaned with water, and grouped based on the similarity in morphological shape and counted from each group / type, then put in a plastic bag and preserved with $4 \%$ Formalin, then transferred into a sample bottle containing alcohol $70 \%$. Taken to the laboratory to be identified. This method is quite effective as has been done [7]-[9].

b) Soil Macrofauna Identification 
Macrofauna samples of preserved soil taken from the field were first grouped according to their types, then determined and identified by looking at the morphological shape with the help of loops, binocular stereo microscopes, and using several reference books according to: Sims \& Easton [10]-[16].

c) Measurement of Soil Physical and Chemical Properties

Measurement of the physical and chemical properties of the soil is done directly in the field (in situ), and in the laboratory as follows:

Field (in situ)

Soil in each square (plot sampling) measured relative humidity, temperature, and soil $\mathrm{pH}$. Measurement of relative humidity, temperature, $\mathrm{pH}$ of the soil before the soil is taken from the square. Relative humidity and soil $\mathrm{pH}$ are measured using a Soil Tester, and soil temperature is measured using a Soil Thermometer.

d) Data Analysis

Types of soil macrofauna and the number of individuals of each type obtained were calculated: Population density of each species, Diversity Index, and Equity Index [8][17] using the following formula:

(a) Density

$\mathrm{D}=($ Amount of species individuals $) /($ Total amount of all individuals $)$

(b) Diversity Index (H')

$\mathrm{H}^{\prime}=\sum(\mathrm{i}=1)^{\wedge} \mathrm{s}$ [pi lnipi $\Omega$

Where: $\mathrm{H}=$ diversity index, $\mathrm{pi}=$ proportion of species $\mathrm{i}$ in the community (ni / $\mathrm{N}$ )

$\mathrm{s}=$ number of species in the community.

(c) Equitability Index (E)

$` \mathrm{E}=\mathrm{H}^{\prime} / \mathrm{Hmax}$

Where :

$\mathrm{E}=$ Equitability Index, $\mathrm{H}^{\prime}=$ Diversity Index, $\mathrm{H} \max =\ln \mathrm{S}(\mathrm{S}=$ number of genus $)$

The Shanon-Wiener Index Criteria are often used to interpret diversity, namely: 
(1) $\mathrm{H}^{\prime}<1$, low diversity, distribution of the number of individuals of each species or low genera, stability of low communities and conditions of soil communities have been heavily polluted.

(2) $1 \leq \mathrm{H}^{\prime}<3$, diversity is classified as moderate, distribution of the number of individuals of each species or genera is moderate, the stability of moderate communities and land communities has been moderately polluted.

(3) $H^{\prime} \geq 3$, diversity is classified as high, the distribution of individuals of each species or genera is high and the soil community is still good or not polluted.

The assessment category of the Equitability Index (E) according to Odum [18].

(1) A. $\mathrm{E} \leq 0.4=$ Low uniformity, depressed community

(2) B. $0,4<\mathrm{E} \leq 0,6=$ Medium uniformity, unstable community

(3) C. $\mathrm{E} \geq 0.6=$ High uniformity, stable community

\section{Result and Discussion}

\subsection{Types and Density of Soil Macrofauna}

Results of research conducted on the oil palm plantation area of PT. Supra Matra Abadi, 15 (fifteen) soil macrofauna obtained species which belong to 2 (two) phyla, 4 (class) classes, 9 (nine) orders, 12 (twelve) families, 15 (fifteen) species, such as listed in Table 1.

From Table 1 it can be seen that the most widely obtained soil macrofauna is from the Arthropod Phylum, which consists of 4 (four) Classes, namely the Arachnid Class, consisting of 1 Order, 1 Family, and 1 Genus / Species; Chilopoda class (1 order, 1 family, and 1 genus / species); Insect (5 orders, 7 families, 10 species), and Malacostraca Class (1 order, 1 family, and 1 genus / species). Whereas the least found soil macrofauna is from the phylum Annelida, which consists of 1 (one) class, namely Chaetopoda consisting of 1 order, 2 families, 2 species. The large number of soil macrofauna from the Arthropod phylum obtained in the area of oil palm plantations is due to the large amount of soil macrofauna of this phylum that has a large number of species and is widespread, both in the lowlands and highlands, and has a wide range of tolerance to environmental conditions, such as temperature, humidity, $\mathrm{pH}$, and the presence of basic vegetation as a source of nutrients, habitat, shelter, and breeding, which plays a role in maintaining the balance of the soil ecosystem.

Arthropods are the largest phyla in the animal kingdom. The number of species is $80 \%$ of the number of known animal species. The many types of arthropods and their wide distribution makes their presence have a large impact on ecosystems on earth. Furthermore, Wallwork [17] states that the Arthropod phylum is a group of soil animals which generally shows the highest 
dominance among the organisms that compose other soil animal communities, having a high distribution and tolerance range to the physical-chemical characteristics of their environment. Most soil macro-arthropod animals are soil digging animals, mainly from groups of insects (insects) that live under plant litter and actively improve soil structure.

From Table 1. It is also seen that the soil macrofauna that is mostly found is from the Class of Insect, this is because Insect is a group of fauna that has a large number of species, spread, and a very wide tolerance range, and is found mostly below the ground surface, such as the forest floor, grassland, plantation and agricultural areas. Some research on soil macrofauna as has been done by several researchers showed that soil macrofauna from Insect class was the most common [1],[19]-[24].

Based on the area of the research location, the number of soil macrofauna species that was more obtained was in the area of the garden which was given fertilizer with palm oil liquid waste (Land Application), which was as many as 12 species, whereas in the area of the garden which was not fertilized with palm oil liquid waste (Non Land Application) as many as 10 species. Based on the population density value of soil macrofauna, the highest total density value was obtained in the area of gardens that were not fertilized with palm oil liquid waste (Non Land Application), as many as 282.15 individuals / $\mathrm{m} 2$, while in the garden area which was fertilized with coconut liquid waste oil palm (Land Application) obtained as many as 163.30 individuals / $\mathrm{m} 2$, this is because in the area of the garden that is not fertilized with palm oil liquid waste (Non Land Application) found that species dominate with a population density value of 222.20 individuals / m2, namely from earthworm species (Pontoscolec corethrurus), as shown in Table 4.2 .

Arlen [1] states that Pontoscolex corethrurus is a species commonly found on oil palm plantations. Furthermore Darmi [25] explained that Pontoscolex corethrurus is an earthworm species that has adaptability, and wide tolerance to various environmental conditions, besides that this earthworm has the ability to consume soil with low quality organic matter.

Table 1. Classification of Soil Macrofauna Obtained at the Research Location at the PT. Supra Matra Abadi, Teluk Panji, Kecamatan Kampung Rakyat, South Labuhanbatu Regency.

\begin{tabular}{cccc} 
& & & \multicolumn{2}{c}{ Location } \\
\cline { 3 - 4 } Phyla/Class & Order \& Famili & Genera/Species & Local Name \\
$n$ & & LA \\
& & LA & \\
\hline
\end{tabular}

1. Annelida :

1) Chaetopoda 1. Oligochaeta

1) Glossoscolecidae

1) Pontoscolec corethrurus

2) Enchytraeidae

2) Fridericia $\mathrm{sp}$

Cacing tanah $+\quad+$

2. Arthropoda :

1. Araneae

1) Arachnida

Cacing tanah - +
1) Linyphiidae
3) Tapinopa
Laba-laba $\quad+\quad+$

3) Tapinopa 
2) Chilopoda

3) Insecta

4) Malacostraca
1. Geophilomorpha

1) Geophilidae

1. Blattodea

1) Blattidae

2) Ectobiidae

2. Coleoptera

1) Scarabaeidae

3. Dermaptera

1) Labiidae

4. Hymenoptera

1) Formicidae
5. Orthoptera

1) Gryllidae

2) Gryllotalpidae

6. Isopoda

1) Philosciidae
4) Geophilus flavus

5) Blatta orientalis

6) Blattella germanica

7) Larva Scarabaeidae

8) Vostax apicedentatus

9) Anthobosca insularis

10)Monomorium pharaosis

11) Odontoponera denticulata

12) Odontoponera transversa

13) Gryllus pennsylvanicus

14) Gryllotalpa brachyptera
$\underset{\mathrm{ng}}{\operatorname{Lipan} / \text { Kelaba }}+\quad+$

Kecoak tanah Kecoak jerman

Larva Kumbang

Cecopet kecil

Semut bersayap Semut Merah $+\quad+$ Semut Hitam $\quad+\quad+$ Semut Hitam - $\quad+$

15) Philoscia muscorum
Jangkrik

Anjing

Tanah

\begin{tabular}{lrr}
\hline Total amount of species each location & 10 & 12 \\
\hline Total amount of species all location & 15 & \\
\hline Keterangan :Non LA = Non Land Application $;$ LA = Land Application $;+$ = Obtained : - = Not Obtained &
\end{tabular}

Wallwork [17] explains that soil fauna in carrying out its life activities is very much determined by environmental factors, both abiotic and biotic factors where it is located (living), such as physical, chemical, biotic, and availability of food, as well as how to cultivate land. in general can affect soil fauna populations, both the presence, distribution, abundance and diversity of their species.

\subsection{Diversity Index (H') dan Equatability (E) Soil Macrofauna}

The results of data analysis of Diversity (Diversity) index values and Equitability (Uniformity) as shown in Table 2 found that the location of plantations that are fertilized with palm oil mill effluent (Land Application) has a diversity index value $\left(\mathrm{H}^{\prime}\right)$ of 2.35 with The criteria for diversity are classified as moderate, the distribution of the number of individuals per species or moderate genera, the stability of the moderate community and the soil community have been polluted moderately, and the uniformity index (E) 0.95 with the criteria of High uniformity, 
stable community. This situation is much better when compared to the area of gardens that are not fertilized with palm oil liquid waste (Non Land Application).

Tabel 2. Type, Density (individual $\left./ \mathrm{m}^{2}\right)$, Diversity Index Value $\left(\mathrm{H}^{\prime}\right)$, and Soil Macrofauna Equitability in the Oil Palm Plantation Area.

\begin{tabular}{|c|c|c|c|c|c|c|}
\hline \multirow{2}{*}{ Species } & \multicolumn{3}{|c|}{ Non LA Location } & \multicolumn{3}{|c|}{ LA Location } \\
\hline & $\mathrm{K}$ & $\mathrm{H}^{\prime}$ & $E$ & $\mathrm{~K}$ & $\mathrm{H}^{\prime}$ & $\mathrm{E}$ \\
\hline \multicolumn{7}{|l|}{ A. Annelida : } \\
\hline 1. Fridericia $\mathrm{sp}$ & - & & & 6.66 & & \\
\hline 2. Pontoscolex corethrurus & 222.20 & & & 33.33 & & \\
\hline \multicolumn{7}{|l|}{ B. Arthropoda : } \\
\hline 3. Tapinopa bilineata & 6.66 & & & 13.33 & & \\
\hline 4. Geophilus flavus & 4.44 & & & 11.11 & & \\
\hline 5. Blatta orientalis & 6.66 & & & 15.55 & & \\
\hline 6. Blatella germanica & 4.44 & & & - & & \\
\hline 7. Larva Scarabaeidae & - & 007 & 042 & 11.11 & 23 & 005 \\
\hline 8. Vostax apicedentatus & 6.66 & 0.91 & 0.42 & 11.11 & 2.35 & 0.95 \\
\hline 9. Anthobosca insularis & - & & & 6.66 & & \\
\hline 10. Monomorium pharaosis & 11.11 & & & 11.11 & & \\
\hline 11. Odontoponera & 6.66 & & & & & \\
\hline denticulata & & & & 11.11 & & \\
\hline 12. Odontoponera transversa & - & & & 26.66 & & \\
\hline 13. Gryllus pennsylvanicus & - & & & 6.66 & & \\
\hline 14. Gryllotalpa brachyptera & 6.66 & & & - & & \\
\hline 15. Philoscia muscorum & 6.66 & & & - & & \\
\hline TOTAL & 282.15 & & & 63.30 & & \\
\hline
\end{tabular}

Information : $\mathrm{K}=$ Density $\left(\right.$ individual $\left./ \mathrm{m}^{2}\right) ; \mathrm{H}^{\prime}=$ Diversity Index; $\mathrm{E}=$ Equitability Index

In the area which is not fertilized with palm oil liquid waste (Non Land Application) only has a diversity index value $\left(\mathrm{H}^{\prime}\right)$ of 0.97 with low diversity criteria. distribution of the number of individuals of each species or low genera, stability of low communities and conditions of land communities has been heavily polluted, and the index value of uniformity (E) is 0.42 with moderate uniformity criteria, unstable community.

These results indicate that the condition of the oil palm plantation ecosystem which is fertilized with palm oil mill effluent (Land Application) which contributes nutrients, as well as other soil chemistry can support life, diversity, and uniformity of soil macrofauna which is much better when compared to plantation area that is not fertilized with palm oil liquid waste (Non Land Application).

\section{Conclusion}

From the results of research that has been done about the Existence of Land Macrofauna on Oil Palm Plantation Land of PT. Supra Matra Abadi can be concluded as follows: 
4.1 Has 15 species of soil macrofauna which are grouped into 2 phyla, 5 classes, 9 orders, 12 families, and 15 genera.

4.2 The highest density value in the garden area that is not owned by fertilizer with palm oil liquid waste (Non-Land Application) is 282.15 ind / $\mathrm{m} 2$ and the lowest density value in the garden area which is fertilized with palm oil waste (Land Application) is 163, 30 ind / $\mathrm{m} 2$.

4.3 Diversity index value and the highest value in the area given fertilizer with a higher value of 2.35 , and a diversity value of 0.95 , and a uniformity value of 0.95 , which means a higher value than the economic value. palm oil mill wastewater can support the life, contribution and uniformity of soil macrofauna.

\section{Suggestion}

To get better results from research in the dry and rainy seasons, as well as before and after applying fertilizers (inorganic and organic), as well as providing pesticides. To improve the quality of soil fauna which is important in increasing soil fertility and increasing ecosystem balance.

\section{REFERENCES}

[1] Arlen, H. J. Study on the effect of fertilization with palm oil mill liquid waste into plantation areas on earthworms to biologically monitor soil quality. [Thesis]. Medan: University of North Sumatra, Postgraduate Program. Pp. 18, 21, 22. 1998.

[2] Dewi, W.S. Soil biodiversity in various land use systems. Enviro. Sebelas Maret University. Surakarta 1 (2): 16-21. 2001.

[3] Anwar, K., S. Sabiham, B. Sumawinata, A. Sapei, dan T. Alihamsyah. Effect of straw compost on soil quality, solubility of $\mathrm{Fe} 2+$ and $\mathrm{SO} 42$ - and rice production in soil sulfate soil. Journal of Land and Climate. 24: 29-39. 2006

[4] Hanafiah, K. A., Napoleon, A., Ghofar, N., Soil biology ecology \& soil microbiology, Rajagrafindo Persada: Jakarta, Page 26. 2010.

[5] Foth, H. D., Basics of soil science. Soenartono Adi Soemarto's translation. Sixth edition. Jakarta: Erlangga. 1994.

[6] Kartini, L. Organic agriculture as the future of agriculture. national proceedings of the seminar on agricultural technology development in an effort to support national food security. BPTP Bali, Center for Research and Development of Socio Economic Agriculture. Bogor. Thing. 98-105. 2000.

[7] Adianto. Agricultural biology (manure, vegetable organic fertilizer and insecticide). Second edition. IKAPI Alumni Publisher. Bandung. 1983.

[8] Suin, N. M. Ecological method. 2nd edition. Andalas University. Padang. 2002.

[9] Suin, N. M. Soil animal ecology. Issue 4. Jakarta Literacy Publisher in Collaboration with the Center for Inter-University of Life Sciences. Bandung Institute of Technology. 2012.

[10] Sim, R. W. and Easton, E. G. A numerical revision of the earthworm genus Pheretima auct. (Megascolecidae: Oligochaeta) with the recognition of new genera \& an appendix on the earthworm collected by the royal society North Borneo expedition. Biological $j$ Linn Soc. Vol. 4:169-268. 1972.

[11] Arnett, R. H. J. R., Richard, L., and Jacques, J.R. Guide to Insects. New York: Simon \& Schuster Inc. 1981.

[12] Dindal, D. L. Soil biology guide. New York: State University of New York. 1990. 
[13] Borror, D. J., Triplehorn, C. A., and Johnson, N. F. Introduction to insect study. Sixth Edition. Translated by: Partosoedjono, S. and Brotowidjoyo, M. D. Yogyakrata: Gadjah Mada University Press. 1992.

[14] Gibb, T. J. andOseto, C. Y. Arthropod collection and identification (field and laboratory technique). British: Elsevier Academic Press. 2006.

[15] Nardi, J. B. Life in the soil (a guide for naturalists and gardeners). The University of Chicago Press. Chicago. 2007.

[16] Ruiz, N., Lavelle, P and Jimenez. Soil macrofauna field manual. FAO. Rome. 2008.

[17] Wallwork, J. A., Ecology of soil animal. Mc. Graw Hill Book Company. London. 1970.

[18] Odum, E.P. Fundamental of ecology. Gadjah Mada University Press. Yogyakarta. 1971.

[19] Sugiyarto., Wijaya, D., Rahayu, S. Y. Biodiversity of land surface animals in various forest stands around the japanese cave, bkph nglerak, lawu utara, karanganyar regency. Biodiversity 3 (1): 196 - 200. 2002.

[20] Muhammad, A. Community composition and distribution of soil macrofauna in the biotopes of the siranggas wildlife reserve area, salak district, pakpak barat regency. [Thesis]. Medan: University of North Sumatra. 2007.

[21] Nusroh, Z. Study of soil macrofauna diversity under different palawija plants in dry land during the rainy season. [Thesis]. Surakarta: Eleven University in March. 2007.

[22] Prasetio, Y. Soil macrofauna diversity in several natural and cultivated ecosystems in pelalawan regency, riau province. [Thesis]. Bogor: Bogor Agricultural University. 2008.

[23] Ariani, D. Soil makrofauna community composition to biologically monitor soil quality in PTPN II sampali plantation area percut sei tuan district. [Thesis]. Medan: University of Sumatera Utara. 2009.

[24] Peritika, M. Z. Soil macrofauna diversity in various sloping land agroforestry patterns in wonogiri regency, central java. [Thesis]. Sebelas Maret University. 2010.

[25] Darmi. Litter type preference and speed of litter decomposition by ponthosax corethrurus tnaha worm. UNIB Research Journal. 9 (3): 138-141. 2003. 